\title{
Behaviour of two demoiselle species (Calopteryx splendens, C. virgo) during social interaction: a signal or a symptom?
}

\author{
Поведение двух видов равнокрылых стрекоз красотки блестящей \\ Calopteryx splendens Harris, 1780 и красотки-девушки \\ C. virgo Linnaeus, 1758 (Odonata, Calopterygidae)
}

\section{E.N. Panov ${ }^{1 *}$, A.S. Opaev ${ }^{1}$, E.Yu. Pavlova ${ }^{1}$, V.A. Nepomnyashchikh ${ }^{2}$ Е.Н. Панов ${ }^{1 *}$, А.С. Опаев ${ }^{1}$, Е.Ю. Павлова ${ }^{1}$, В.А. Непомнящих ${ }^{2}$}

\footnotetext{
${ }^{1}$ A.N. Severtsov Institute of Ecology and Evolution, Russian Academy of Sciences, Leninsky prosp., 33, Moscow, 119071 Russia.

${ }^{1}$ Институт проблем экологии и эволюции им. А.Н. Северцова РАН, Ленинский просп., 33, Москва 119071 Россия.

${ }^{2}$ Institute of Biology of Inland Waters, Russian Academy of Sciences, Borok, 152742 Russia.

${ }^{2}$ Институт биологии внутренних вод РАН, п. Борок, Ярославская область, 152742 Россия.

* Corresponding author. E-mail: panoven@mail.ru
}

KEY WORDS: damselfly, agonistic behaviour, evolution of courtship behaviour, sexual selection.

КЛЮЧЕВЫЕ СЛОВА: стрекоза, агонистическое поведение, эволюция поведения ухаживания, половой отбор.

ABSTRACT. Based on the analysis of video recordings, obtained during five field seasons, we suggest a pattern of analytical description of damselfly (Zygoptera: Calopterygidae) behaviour in a broad spectrum of social contexts. The arrays of motor coordinations and their place in social interactions are studied comparatively and in the temporal dynamic. The first description of the full set of behaviours of Banded Demoiselles Calopteryx splendens is given; the respective data for Beautiful Demoiselles $C$. virgo are significantly updated, and their interpretations are revised. The whole system of species-specific behaviour of each species is presented as a systemic syndrome. We provide critique of the currently prevailing interpretations of functional explanations of damselfly behaviour, which are based on openly anthropomorphic approaches. We suggest an alternative approach, based on an earlier paradigm of field and analytical ethology, neglected in the recent decades.

РЕЗЮМЕ. На основе анализа видеозаписей, полученных в ходе пяти полевых сезонов, предложена схема аналитического описания поведения стрекоз красоток (Zygoptera: Calopterygidae) в широком спектре социальных взаимодействий. В сравнительном плане рассмотрены репертуары моторных координаций и их место в социальном процессе, проанализированном во временной динамике. Полное описание соответствующих форм поведения красотки блестящей Calopteryx splendens приводится впервые, данные по второму виду существенно дополнены, а их интерпретации поданы в новом свете. Весь комплекс видоспецифического поведения каждого вида представлен в качестве синдрома систем- ного характера. Подвержены серьезной критике трактовки функциональных объяснений поведения стрекоз, господствующие в современной литературе по этим насекомым и основанные на откровенном антропоморфизме. Этому подходу противопоставлен совершенно иной, призывающий к возврату к оставленным в последние десятилетия методам и принципам, разработанным ранее в рамках полевой и аналитической этологии.

Dragonflies and damselflies are a group of model organisms very suitable for studying ecology and evolution. These studies formed the discipline of odonatology. In the recent decades, much data has been obtained on a broad spectrum of biology aspects of Calopterygidae species. It was made possible due to many features that make the study of these insects as model organisms very suitable: large numbers, ease of capture for studying various aspects of morphology, physiology, ontogenesis and synecology of different species.

The study of behaviour of damselflies is completely dominated by the functional approach. In this framework, any movement or a sequence (i.e. a sequence of locomotory acts) observed during social interactions of damselflies, is a priori treated as a component of the socalled "signalling" behaviour. It is assumed that every such action is closely linked to the colouration of an insect and is aimed at displaying it to the social partner. In other words, these are all signals, and each of them has its own communicative function. On the basis of these ideas, most general hypotheses are suggested, concerning the causes and mechanisms of evolution of this type of behaviour. The dominant concept is the idea of the moving force of sexual selection which is be- 
lieved to form the signals of maximum efficiency (honest signalling).

Unfortunately, these theoretical concepts are often based on quite insufficient empirical data. Among the huge number of sources we were able to find just a single publication which rather stringently described what can be called the morphology of behaviour of the species [Pajunen, 1966]. Usually the authors ignore this labour-consuming stage of description and analysis of what actually happens when the individuals interact.

It is not until very recently that publications have emerged which try to describe the patterns of social interactions in sufficient detail [Günther et al., 2014; Günther, 2015]. Unfortunately, these studies currently focus on exotic species that can be only observed briefly. The data obtained are used as further illustration of the established concepts on the essence of communication and evolution of "signal structures" in dragonflies. At the same time, common species which are easily accessible for ethological research remain practically unstudied in regard to morphology of their communicative behaviour.

Here we report the results of long-term studies on these aspects of ethology of two common European zygopterans, Banded Demoiselles Calopteryx splenden Harris, 1780 and Beautiful Demoiselles C. virgo Linnaeus, 1758 . Morphology of their behaviour is analysed in a comparative aspect. The idea of our approach is that we show how pairwise interactions between the individuals fit in the general framework of interactions in the dense reproductive settlements of these species. We call this the social process.

We have previously shown the following main difference in behavioural ecology between these species. During the reproductive periods, male and female Banded Demoiselles spend the night in the grassy coastal vegetation in the areas of their daytime concentrations. Conversely, Beautiful Demoiselles in the evening leave the closer vicinity of water and probably spend the night in the canopy. Therefore, the space inhabited by the former species may with a some degree of approximation be characterized as being 2-D, and by the latter species as 3-D.

We have found that males of these species show a varying degree of site tenacity to their locations within the aggregation. The mean period of stay within home ranges in male Banded Demoiselles is 5.8-6.7 days, whereas in Beautiful Demoiselles it is considerably shorter, just 3.7 days. This difference is attributed not to a lower survival rate of male Beautiful Demoiselles after marking, but rather to them switching home ranges [Stettmer, 1966; Opaev, Panov, in press]. One can assume that the reason is between-species difference in the mobility of individuals within their living space during the day: sedentary lifestyle of Banded Demoiselles and daily movements of Beautiful Demoiselles to and from their roosts.

In this paper we attempt to find similar relationships between the aforementioned characteristics of behav- ioural ecology of each species and particular forms of behaviour which are usually ascribed signal function. We assumed that similar correlations may exist between different categories of communication, e.g. between male-male interactions and socio-sexual behaviour. In other words, we attempt to present the whole array of species-specific behaviour as a systemic syndrome.

The second question is how functional and effective are various forms of behaviour of these damselflies as means of communication. May it be that many of them are just a byproduct of increased level of activation intense social contexts [Howse, 1975; Corbet, 1991]. Should such actions be treated as signals which have an addressee, or they are just symptoms of the inner condition of the actor? The 'signal - symptom' opposition has been extensively treated by Wenner [2002].

\section{Study species, Material and Methods}

Zygopterid damselflies Calopteryx splendens and $C$. virgo belong to the same young phylum of the Calopterygidae family, but to its different branches (Fig. 1). They show some significant difference in morphology, ecological preferences and in behaviour [Rüppell, 1989; Stettmer, 1996; Tynkkynen et al., 2008; Kuitunen, Gorb, 2011; Wellenreuther et al., 2012].

The study was performed in Vladimir Region of Russia near Mstyora Town in 2010-2014. Some additional data have been collected in 2009 and 2015. In our study area Banded Demoiselles form reproductive settlements along Tyumba River with a slow flow and warm water. Settlements of Beautiful Demoiselles occur along another Tara River, which has a rapid flow, many underwater springs, and thus a much colder water.

Damselflies were captured by butterfly net and marked by a permanent marker. A combination of marks was made on abdomen and wings. After marking, an insect was fixed by an elastic band against plotting paper and photographed. Subsequently we measured the length of abdomen (from the beginning of the first segment until the end of superior anal appendage) and

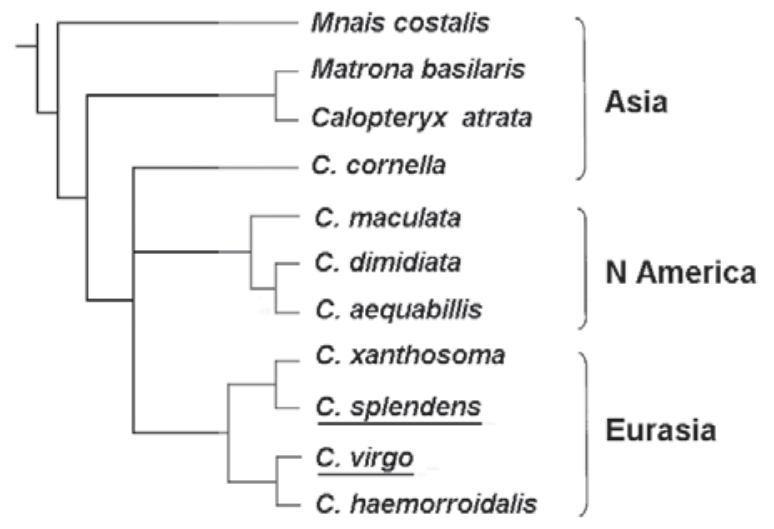

Fig. 1. Phylogeny of damselflies. After Misof et al., 2000.

Рис. 1. Филогения стрекоз красоток Старого Света. Из: Misof et al., 2000. 
the forewing (from the base to the tip) in Adobe Photoshop CS4 to the nearest $0.1 \mathrm{~mm}$. We captured a total of 203 male and 56 female Banded Demoiselles, of which 138 males and 15 females were re-encountered in the subsequent days [Opaev, Panov, in press]. We also captured 180 male and 19 female Beautiful Demoiselles.

Observations and captures of damselflies at study plots were performed daily during 2-4 hours. We also continuously videotaped behaviour of one or several focal males, also paying attention to other events in the focal area of the reproductive aggregation.

We mapped the study plots and marked the position of vegetation patches with a size of ca. $0.5 \mathrm{~m}^{2}$ that were used as home ranges by demoiselle males. These patches were numbered, and during observations, patch number in which a male was observed, was noted (up to four patches in one day). These males were assumed to be territorial in a respective day of observation.

Video recordings were analyzed with the help of Pinnacle Studio 14 software. The degree of opening the wings in the wing clapping (WC) locomotion was estimated by eye along the 6 -grade scale, from the minimum score (each wing deviates from the vertical by 30 $\left.{ }^{\circ}\right)$ to the maximum score (the wings are nearly horizontal) with a $30^{\circ}$ step.

Descriptions of behaviour. Detailed descriptions of social and communicative behaviour have only been available for Beautiful Demoiselles, primarily for malemale interactions [Pajunen, 1966]. What concerns Banded Demoiselles, only passing records on this subject exist, so brief that it is difficult to understand the subject on their basis [Plaistow, Siva-Jothy, 1996].

In our cataloguing of behavioural forms we did not follow the common procedure when the components are a priori divided into territorial behaviour, based on male-male antagonistic interactions, and sexual behaviour [Pajunen, 1966; review: Córdoba-Aguilar, Cordero-Rivera, 2005: 866-874; Günther et al., 2014; Günther, 2015]. We start by dealing with the patterns as elements of structure without assuming any functional significance. It is only subsequently that their use by damselflies is analysed in four different social contexts: (1) without any partner (solitary); (2) in agonistic interactions; (3) preceding copulation; (4) when a female oviposits in the presence of a male.

The whole array of means which are usually called as "signal" ones, are treated by us as a hierarchical structure. The lowest, basic level of integration is represented by elementary locomotions. They may form constructs of the first level, that can be called "postures". The next, second level, consists of different variants of locomotory activity during flight.

The repertoires of patterns we are interested in follow the general trend in both species studied, with more or less pronounced variation in their occurrence between the species. Therefore we present the general list of patterns.

Elementary locomotions: 1. Wing spreading (WS); 2. Wing clapping (WC); 3. Curling the distal part of the abdomen (CA).

Postures: 1. Combination of wing spreading and raising the abdomen and curling its tip (WS-CA). 2. Standing flight (SF — wing trembling when on substrate or on water surface).

Aerial locomotions. 1. Standard linear flight (LF); 2. Dancing flight (DF); 3. Curving flight (CF); 4. Rushing flight (RF); 5. Fluttering flight (FF); 6. Dropping to the water (D).

In most cases, frequency distribution of events that characterised the behaviour of damselflies (e.g. duration of behavioural acts or intervals between these acts) was significantly non-normal (Shapiro-Wilk test, $\mathrm{p}=$ $0.05)$. Therefore we used both Student t-test for comparing means and the non-parametric Mann-Whitney test to compare medians.

Preliminary comments. Below we attempt to show that many of the aforementioned patterns are actually parts of single behavioural constructs, which can be split into parts only as a most rough approximation. For instance, such actions of a male Banded Demoiselle as FF and D, are basically inseparable. When sitting on water surface, to which a male descends by fluttering flight, it performs the same movements by his wings as during such flight (fluttering), and this action immediately grades into a fluttering flight. After WC which a male performs near a female, FF immediately follows.

All this suggests the following conclusion. A sharp distinction between the aforementioned forms of behaviour with their own signal function looks very artificial. The procedure of identification of the eleven behavioural patterns listed earlier is in our case a 'useful fiction'. It marks some signposts in the continuum of empirical data which make it possible to start a disinterested analysis of what happens before our eyes.

In the description of our results we used the concept of "activity centre" of a currently territorial male [Opaev, Panov, in press]. It is the perch which the male is consistently using during the current period.

Another important preliminary comment is that we prefer to speak not of specific motivations (aggressive and sexual ones), but of variations in the general excitement level, which may depend not only on external stimulation, but on endogenous cyclic processes as well.

\section{Results}

\section{Pattern and context: no direct relationship}

The same pattern may be present in the behaviour of damselflies in very different social contexts. It refers to most of the eleven aforementioned motor coordinations and applies to both species. Let us try to look in more detail.

Wing spreading (WS) is typical of both sexes. In males these movements are most apparent when during copulation another male approaches the male holding a female (Fig. 2). 


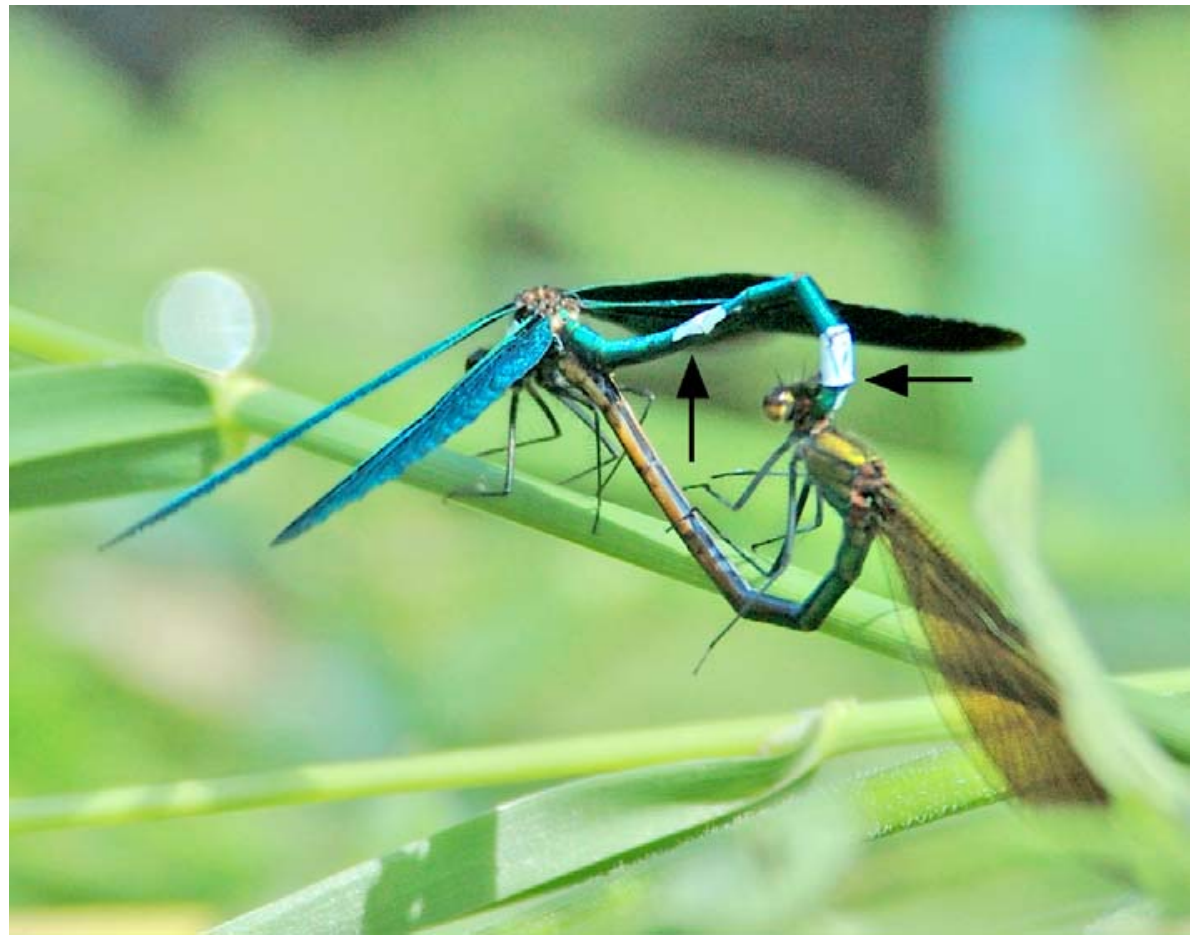

Fig. 2. Wing spreading (WS) by a copulating $C$. virgo male as reaction on another male approach. Arrows show individual marks. Photo: E.N. Panov.

Рис. 2. Раскрывание крыльев копулирующим самцом C. virgo в ответ на приближение другого самца. Стрелками показаны индивидуальные метки особи. Фото Е.Н. Панова.

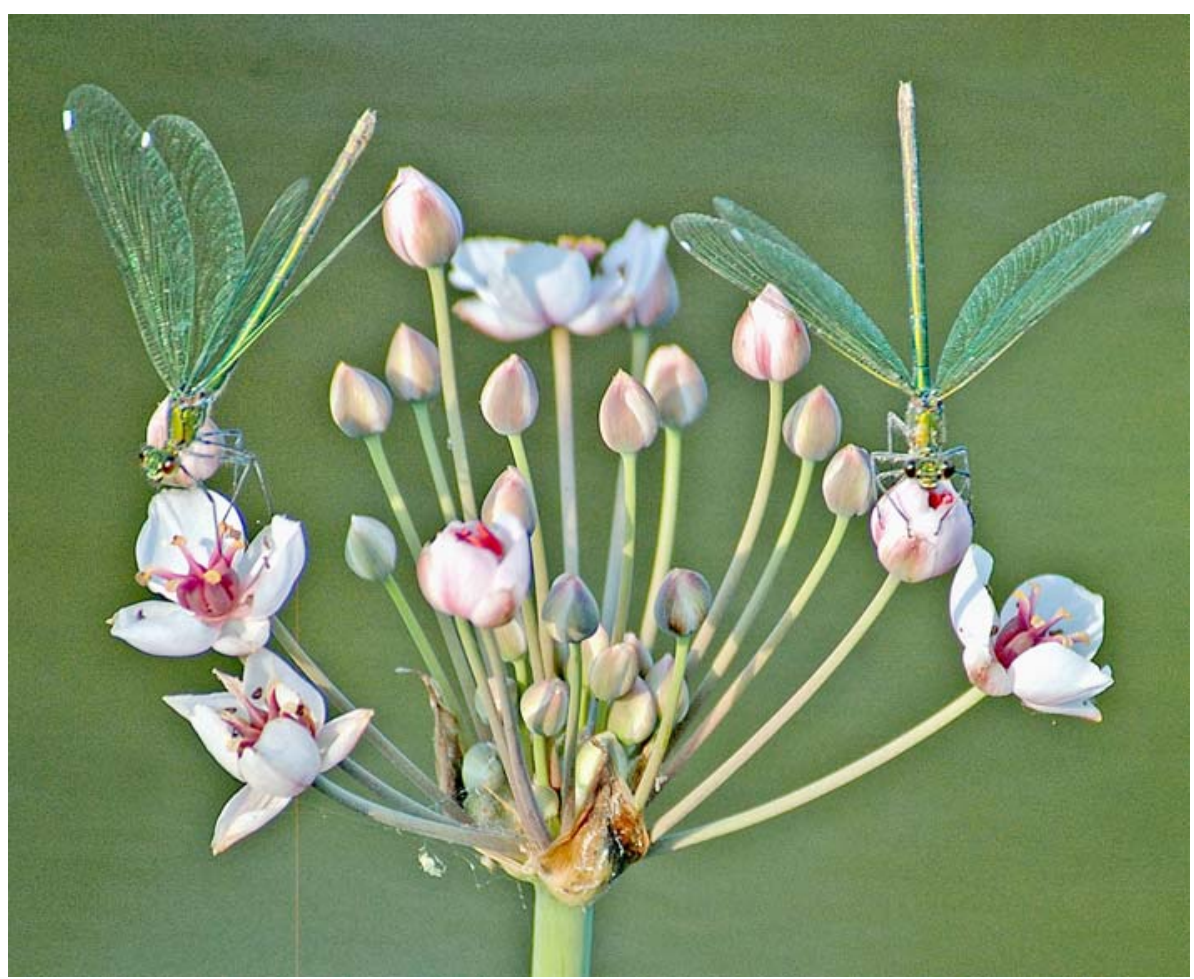

Fig. 3. Partial wing spreading (WS) by C. splendens females when approaching each other. Photo: E.N. Panov.

Рис. 3. Частичное раскрывание крыльев самками C. splendens при сближении друг с другом. Фото Е.Н. Панова. 


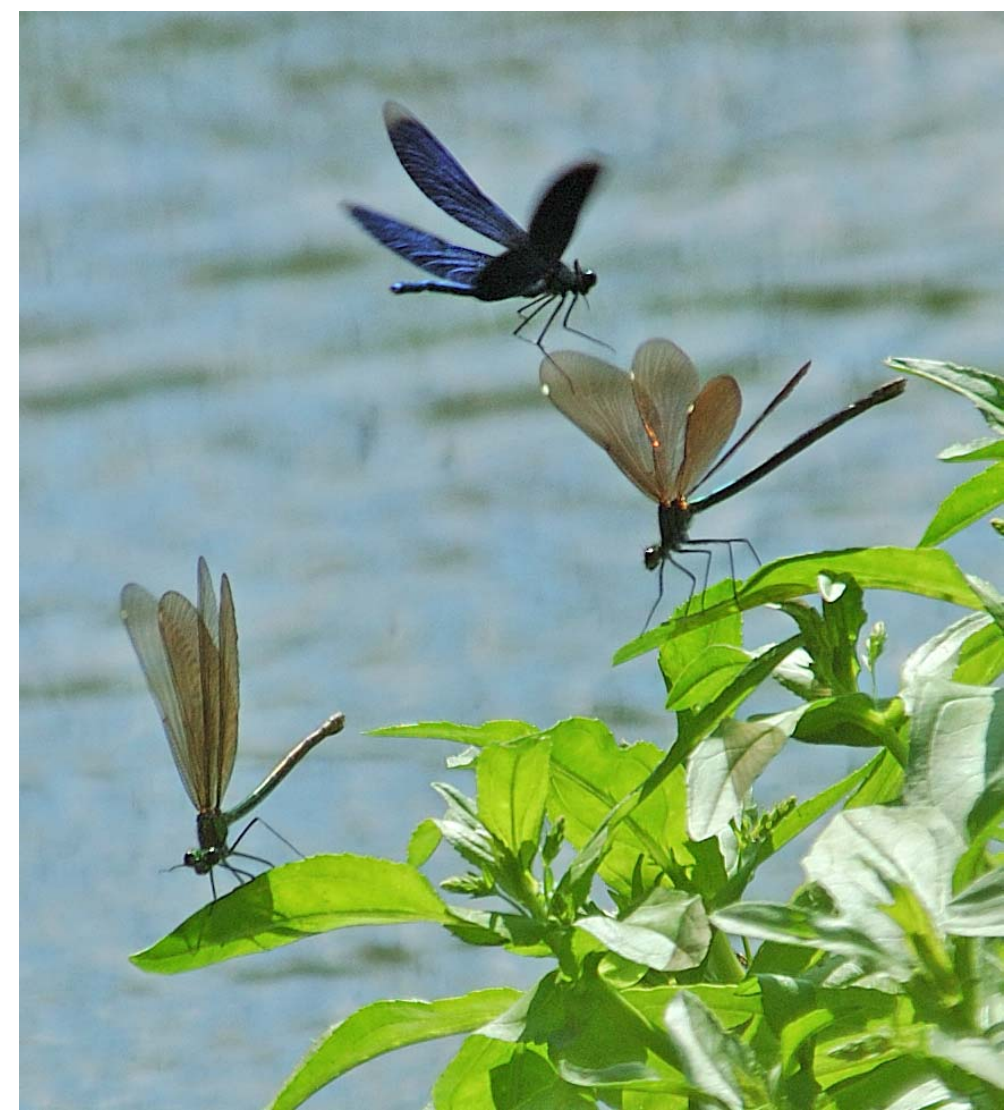

Fig. 4. Partial wing spreading (WS) by $C$. virgo female approaching by a male. Photo: E.N. Panov.

Рис. 4. Частичное раскрывание крыльев самкой $C$. virgo в ответ на попытку садки со стороны самца. Фото Е.Н. Панова.
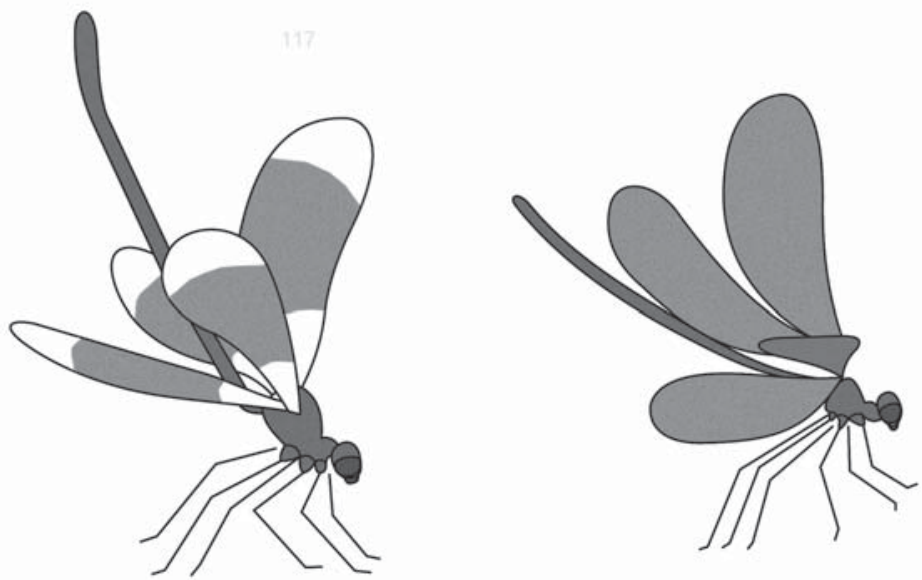

Fig. 5. Postures adopted by C. splendens males (on the left) è $C$. virgo (on the right) in response to another male approach. From videorecording.

Рис. 5. Позы, принимаемые самцами C. splendens (слева) и C. virgo (справа) в ответ на приближение другого самца. По видеокадрам.

In females this is a response to another female approaching (Fig. 3) or to a male trying to copulate with her (Fig. 4). Contrary to what many sources claim, the male often ignores this movement, and the female which makes it, does not fly away and allows the male to grab her [cf. Waage, 1984].
WS is a component of the posture which a sitting male takes when approached by another male. When this response reaches its maximum, male Banded Demoiselles keep the tip of their abdomen in a upright position, nearly perpendicularly to their body axis. Male Beautiful Demoiselles under such circumstances just 

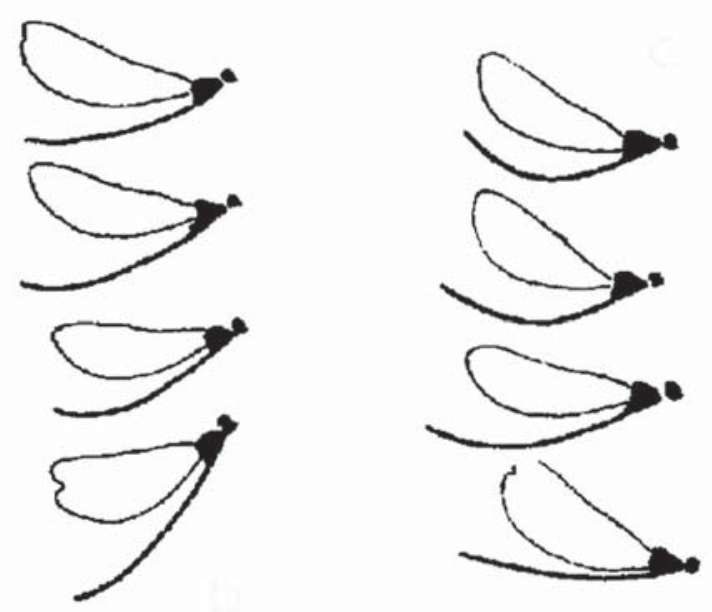

èn. 6. Curling the distal part of the abdomen (CA) in the course of $\ddot{i}$ è joint dancing flight (DF) by $C$. virgo males. After Pajunen, 1966.

Рис. 6. Изгибание брюшка при совместных порхающеепляшущих полетах у самцов C. virgo. Из: [Pajunen, 1966].

slightly rise their abdomen when spreading their wings (Fig. 5). As shown below, this difference may be due to the fact that males of the latter species rarely ignore the individual distance, as is typical of Banded Demoiselle males, which when competing for a perch evict the opponent by approaching it closely.

The same postures are observed in females. Waage [1984: 401] calls them "displays of denial" (of sexual intercourse).

Curling the distal part of the abdomen (CA). As shown in Fig. 5, this component is present in the aforementioned WS action of males. The same is observed in males during dancing flights, which are a standard part of agonistic interactions (Fig. 6). CA has also been observed in the male present near the laying female (Fig. 7).

Wing clapping (WC). In the latter case CA is combined with regular wing clapping. In both species, WC action is rather variable. Rate of wing movement in the initial phase (wing spreading) and the maximum angle from the default position of folded wings may vary substantially. Apart from one-time WC, short series of 4-5 unfinished, jerky movements of this kind are sometimes observed (clapping). It seems that in male Banded Demoiselles the initial phase is less pronounced than in the other species, and that wings, before returning to the initial position, are more often fully spread, at the angle of ca. $150^{\circ}$. In male Beautiful Demoiselles this angle is usually smaller, so that sideward movements of wings are barely detectable, and fully spread wings deviate from the folded position by less than $150^{\circ}$.

WC actions are standard components of male behaviour in three different contexts.

1. Lack of social partners. As an example, we provide a fragment of the record of behaviour of a Beautiful Demoiselle male in such situation. Over $25 \mathrm{~min}$ of observations (7 July 2010) WC has been recorded 50 times. Occurrence of actions, together with its intensity (estimates on a 6-score scale) looked as follows:

Example 1 (14.34) FF — landing - 5566666 fluttering - FF — landing — 4466332 - short flight 2 - take-off and landing - 55566543 - DF together with a neighbour male — landing — 123456 (14.40); (14.44) 256 - gone - DF flights with a neighbour male landing - 312411 - take-off and landing - 4455 pronounced CA (14.48); (14.54) arrived - 152 - short flight - landing - 21456 (14.58).

Other motor coordination, interspersed with $\mathrm{WC}$, are shown bold. Most important is the presence of FF in these sequences, which is usually believed to occur exclusively in the context of pre-mating behaviour of males. Below we show in detail that this is not correct (section on fluttering flight).

2. Before copulation, this pattern is interspersed with FF, which is dominant under such conditions. As a male needs a maximum of 1-2 minutes to prepare for mating, if everything goes well, nearly no time remains for WC. In one case, a male Banded Demoiselle performed just $6 \mathrm{WCs}$ before copulation and 124 after it, until the female submerged into water.

3 . Presence of a male near the female during oviposition. As exemplified by the presented sequence, frequency of occurrence of WC reaches its peak during these situations. The pauses between bouts of $\mathrm{WC}$ are on average $3 \mathrm{~s}$ in male Banded Demoiselles (median time $3 \mathrm{~s}$, mean for 6 males) and $5 \mathrm{~s}$ in male Beautiful Demoiselles (median 6 s, 5 males). The difference between species is statistically significant (Mann-Whitney test, $\pi=0.04$ ).

These data support the general impression of a more "phlegmatic" behaviour of male Beautiful Demoiselles, as compared with the other species. WC is also performed by females of both species.

Standing flight (SF, or trembling). This element is only typical of male Banded Demoiselles. When sitting on the substrate or on water surface, the damselfly vibrates its wings with the same frequency as during FF, but the wings are nearly pressed to the body.

This action is observed in two situations: when the male prepares for mating and when it is present near an ovipositing female. In the former case this element is performed mainly when the male descends to the water surface, when fluttering flights are apparently discontinued for a couple of seconds, but is actually not interrupted. This sequence of actions may be repeated several times, before the male approaches the female to copulate with it. Each time, the male ascends by fluttering flight for several centimetres and then drops to the water again. When on the water surface, it may slightly increase the angle between its wings (clapping, see above) and by their movements it may turn by several degrees to the right and to the left.

When the males are present near the laying females, they perform trembling when staying on the aquatic plants above the water. Usually it happens when the female flies between different positions. Sometimes the 

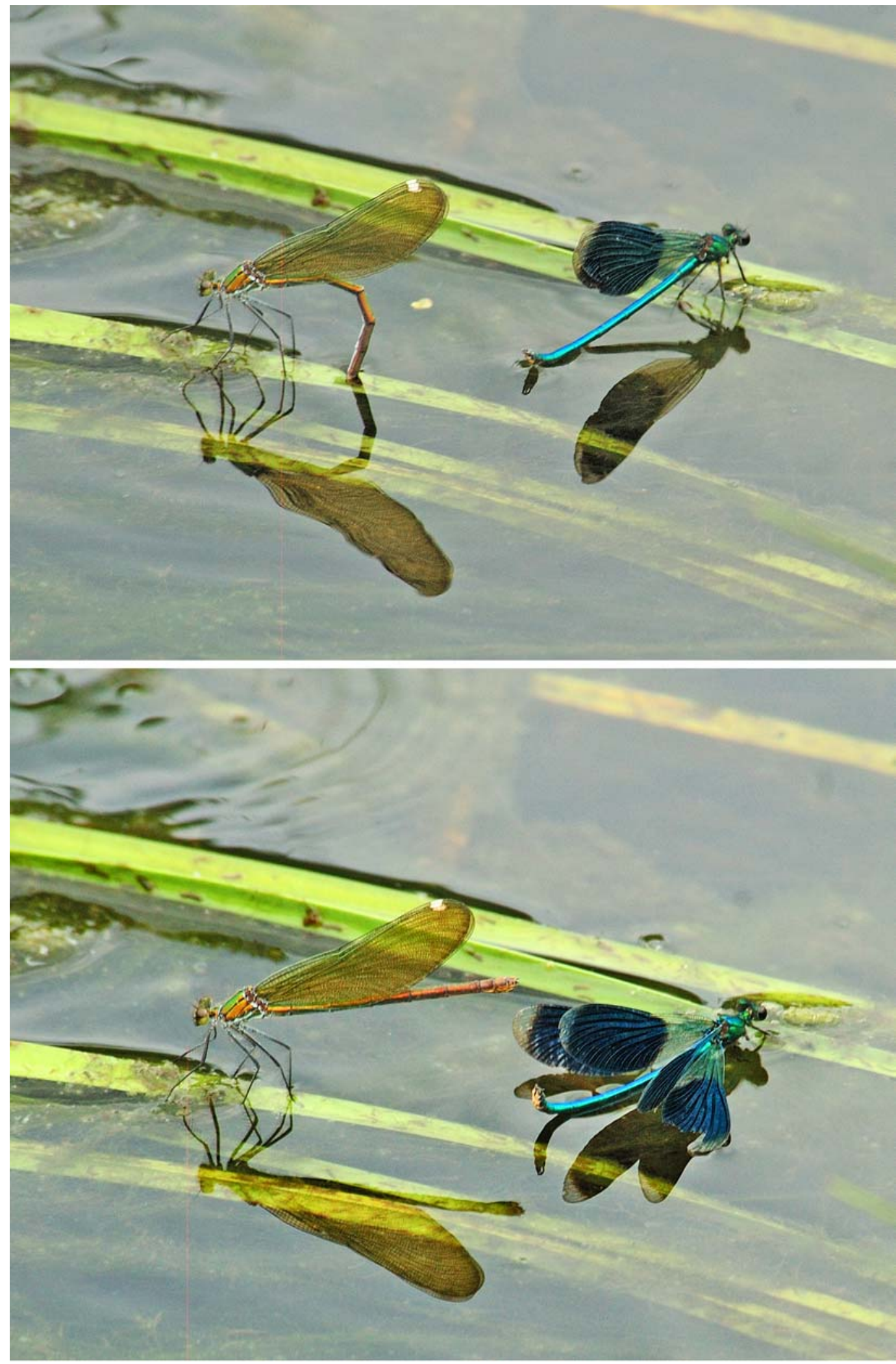

Fig. 7. Wing clapping (WC) and curling the distal part of the abdomen (CA) by a C. splendens male remaining nearby an ovipositing female. Photo: E.N. Panov.

Рис. 7. Хлопки крыльями и изгибание брюшка самцом C. splendens, пребывающим неподалеку от самки, откладывающей яйца. Фото Е.Н. Панова. 
aforementioned actions, typical of preparation for copulation, such as FF and D (dropping to the water) with a subsequent trembling or without it, may be repeated several times.

Beautiful Demoiselle male also drop to the water when a female appears within their home range, but it happens much less frequently and is never accompanied by these actions. Rarity of $\mathrm{D}$ in the pre-copulative behaviour of this species has already been mentioned by Pajunen [1966: 210].

\section{Aerial locomotions}

Pajunen [1966] identifies eight types of flight in male Beautiful Demoiselles. We believe that this is an overestimate, the more so since this author did not clearly distinguish between the structural features of locomotions and the modi of using most of them by males in their interactions. The author himself probably felt so; e.g. he grouped in the 'Lateral threat' section 'reactions which included features intermediate between frontal threat and reversed threat, and mentioned that the relative position of the males change frequently, and the distance between them is not so strictly defined as in the previous types'. Also in other places Pajunen [1966] emphasized the lack of a clear distinction between different types of flight. Our data agree with this approach, contra the view which treats flight types in demoiselles as discrete units with specific signal meanings [e.g. Hilfert-Rüppell, Rüppell, 2013].

Apart from the standard linear flight, we identify four further variants of flight that occur during social interactions.

Dancing flight (DF) is the most commonly observed type of locomotions. It is described by Pajunen [1966] for Beautiful Demoiselles as 'lateral threat', 'frontal threat' and 'reverse threat'.

Two males, most commonly owners of two neighbouring home ranges, fly together some $15-30 \mathrm{~cm}$ one from another, sometimes increasing distance to 1-2 $\mathrm{m}$. Flight is slower than standard linear flight, is fluttering and undulating. The rostral part of body is raised, and the tip of abdomen curled.

It is necessary to emphasize that during such interactions no participant tries to approach the partner closer than the mentioned minimum distance. There is no chaser and the chased, i.e. no male harasses the other one, to say noting of attacks. This interaction may continue for tens of minutes and occurs above the adjacent parts of neighbouring home ranges or above the disputed area. From time to time of the participants lands, but the other immediately displaces him, and the joint flight continues.

This behaviour is equally typical of both species. However, as mentioned by Hilfert-Rüppell and Rüppell [2013], male Beautiful Demoiselles more often change flight direction in the vertical plane and perform the action that we call "jumps".

Curving flight (CF) is described by Pajunen [1966] under two sections, 'rocking' and 'circling'. This author apparently treated them as two different patterns. We suggest that this is the same locomotion. It is linked to certain interactions which occur much less frequently than joint DF of males. Participants of such locomotions keep the distance of $10-15 \mathrm{~cm}$ and fly rapidly, with bends and curves. Sometimes they spiral along the imagined vertical axis. Unlike fluttering flights which always occur just above water surface, during CF damselflies often simultaneously fly 3-4 m up in the air. Even though one may assume that the conflict starts on the basis of claiming a certain area, these flights are not obviously linked to local topography. If an area with a radius of ca. $2 \mathrm{~m}$ is the initial trigger of the conflict, flight paths of opponents may extend for $10 \mathrm{~m}$ and more along the river to both sides.

These interactions are very emotional. They may last for 90 minutes and more. Attention of both participants is fixed to the opponent. Neither of them responds to other males which they may incidentally encounter. Similarly, other males pay no attention to the couple which flies in this fashion and crosses their home range multiple times. If FF of two males may be joined by other males, thus forming a temporary swarm of several individuals, CF interactions never involve more than two males.

The behaviour of opponents rules out the possibility of even a short interruption by landing of a participants, as it may happen in FF. However, if CF last for an hour or longer, curving flights are from time to times interspersed by short sessions of typical FF. These changes are abrupt and unpredictable.

Contrary to the opinion of Pajunen [1966: 204] and Plaistow and Siva-Jothy [1996: 1234], we do not think that when circling (following the usage of these and other authors) one male is chased and the other is the chaser. It seems to us that each male follows his own programme [cf. Hayashi et al., 2012].

In the observation protocols in a splendens aggregation in 2010 ( 35 hours), CF is mentioned 14 times. This behaviour has been observed a comparable number of times (16) in a $C$. virgo aggregation during just 6 hours in 2015. These preliminary data may suggest that $C$. virgo males switch from $\mathrm{DF}$ to $\mathrm{CF}$ locomotions easier than the males of the other species. In other situations, however, male Beautiful Demoiselles seem to be more 'phlegmatic' (see above).

Rushing flight (RF) is very similar in pattern to the aforementioned interactions. However, it is performed solo. It happens in the most charged social contexts. For instance, this is the behaviour of a male when another male tries to approach the female which is ovipositing within his range after mating with territory owner. This situation may result in hijacking of the female by the intruder. Under such situations, rushing flight may with a high probability be expected from the home range owner. He starts to fly rapidly back and forth, getting far beyond his home range. It is worth noting that phases of $\mathrm{RF}$ are often interspersed with FF. In some cases, rapid flights above the water to the right and to the left are observed, which occur exclusively in this fashion. 
Fluttering flight (FF). Pajunen [1966] denoted this type of locomotion by a neutral term "hovering", based on its kinematics. Further in the text this author however called it courtship flight. In most if not all subsequent publications the latter term was used. It is however misleading, because FF is observed not only just before mating, but also in many other contexts.

One example, that a male may perform FF in the absence of a female, is given above, when we mentioned repeated spontaneous wing-clapping movements (WC) of a single male. It is not uncommon that a male, probably as a result of general arousal, enters the FF regime and moves only in this mode. The inertial character of this behaviour is similar to what has been mentioned earlier on non-stop pairwise CF. The male repeatedly flies rather far from his activity centre and returns by FF. It may continue for 10 minutes or more.

A male may enter this condition, for instance, when it have seen a female which flew across his home range, in failed a copulation attempt. Subsequent multiple FF look as a consequence of such external stimulation. However, the shift from standard flight to the FF regime may also happen spontaneously. During short-term increases of the general arousal a male sometimes conflicts with others using FF. And in the mentioned inertial phase, he moves only this way during any contacts with other males.

FF is beyond doubt the standard and necessary tool which enables physical contact between a male and a female during regular (non-violent) mating. However, a detailed description of the process shows that also here the things are less straightforward than mentioned in passing in numerous publications. As an example we present a transcript of a video recording of behaviour of a Banded Demoiselle male during 90 seconds before a successful copulation.

Example 2. 20.15.19 male within his range; 20.15.24 a females flies by - male FF and drops into water; 20.15.27 FF by several centimetres upwards and again drops into water, there WC score 2-3; 20.15.29 FF (a female flies above him) and movement by this type of flight towards the vanishing direction of the female; 20.15 .35 arrived (FF continues), landed on the perch; 20.15.37-20.15.38 two WC score 5; 20.15.42 take-off FF flies rather far away; 20.15.44 returns by the same type of flight - drops into water near the perch, there three WC score 6; 20.15.49-20.15.50 FF flies a circle over the water, landed; 20.15. 52 WC score $5 ; 20.15 .55$ -20.16 .03 FF several circles over the water, landed on the perch; 20.16.04 WC score 5; 20.16.06 WC score 5; 20.16.09 FF several circles over the water; 20.16.12-20.16.15 FF a circle over the water; 20.16.24-20.16.27 FF a circle over the water; $20.16 .38-20.16 .42 \mathbf{F F}$ a circle over the water with a curve; 20.16 .50 take-off from the perch FF $2-3 \mathrm{~cm}$ upwards; 20.16.50 female arrives, the male FF into the water, up to 20.15.59 in the water, there wing clapping, then trembling, jump FF $2-3 \mathrm{~cm}$ upwards and again dropping into the water (the female flies by, for a moment touches down the water ca. $15 \mathrm{~m}$ from the male and then lands to a grass stem); 20.16.00 males takes off $\mathbf{F F}$, approaches the female's perch from below (the female's head is directed away from him), slowly ascends. Approaches FF the female from below, touches the base of her wings by his feet, slides back, sharply turns and sits to her head, and from this position clenches her cervical part by the pincers on the tip of abdomen (20.16. 08).

This is most characteristic in the sense that the male has never performed FF and did not spread his wings in front of the female, as literature sources report. One can see than FF is performed irrespectively of the current position of the female.

Flight kinematics is similar in both species. The amplitude of wing movements is $30-40^{\circ}$ from the horizontal plane, and wingbeat frequency is $40-60 \mathrm{~Hz}$ in Beautiful Demoiselles [Pajunen, 1966] and ca. $40 \mathrm{~Hz}$ in Banded Demoiselles [Rüppell, 1989]. Wings move more than twice as rapidly as during joint flights of males (16 $\mathrm{Hz}$, [Rüppell, 1989]). Just before copulation, flight direction may briefly change back and forth.

Between-species variation is apparent in the general pattern of behaviour of males when their are ready to start physical contact with a female. Male Beautiful Demoiselles take the starting position by hovering 5-10 $\mathrm{cm}$ from the female and aiming by his head exactly towards her. The male usually maintains this position when the female moves within his range of vision (often repeatedly), by following her and makes short moves towards her from time to time. The male does not perform such actions as WC or dropping into water. In this sense, his behaviour looks much more rigid than the behaviour of the other species. As shown in the previous example, the behaviour of Banded Demoiselle males is much more variable. Male Banded Demoiselles usually approach the female for copulation from below, and male Beautiful Demoiselles do that in the same place frontally, or from above.

Unlike male Beautiful Demoiselles, Banded Demoiselles often fly in the FF regime, when they after mating remain near the ovipositing female. Females also use FF-like flight mode when they fly between the oviposition locations during this period.

Pajunen [1966] reports that when male Beautiful Demoiselles chase females, they combine wing flaps like during standard regular flight and like during FF, and also use intermediate variants. Short wing flaps become more frequent when the male approaches the chased female Pajunen [1966: 211]; structure of these flights is analysed in detail by Hilfert-Rüppell and Rüppell [2009].

\section{Social process}

In this section we discuss how the aforementioned motor coordinations fit into the context of social interactions between individuals.

\section{Male-male interactions}

When discussing the behaviour of males which is usually called 'territorial' and 'aggressive', we prefer to use a more neutral term agonistic behaviour. The other two terms seem less precise to us. Home range of a male does not fit the definition of a territory, which is accept- 
ed in the literature on vertebrate behaviour and borrowed from it. Moreover, male-male conflicts are devoid of apparent aggression, as outlined below. Direct contacts between males of the contact aggression type are only observed in the rare cases when a male lays claim on the female which is held by another male. In such moments, one male may capture the head of the other one by his cercae (similarly like capturing a female). However, it happens incidentally and does not look like a deliberate action. Therefore the terms 'attack' and 'fighting', widely used in damselfly literature, seem misleading to us.

Spatial distribution of males. Many males in the aggregation spend most of the time on their perches. It may be a plant stem protruding from the water, or a leaf hanging from the bank. These individual perches are located close one to another: sometimes ca. $1 \mathrm{~m}$ apart, up to 4-5 m. In Banded Demoiselle aggregations some perches are preferred, and others are only rarely occupied. In this species the location of a stable home range owner may shift if the previously used perch is submerged due to water level change. Male Beautiful Demoiselles are generally much more mobile within their aggregation, even short-term.

A Banded Demoiselle male which has abandoned his home range voluntarily, as in such case, or displaced by another male, often remains in the aggregation, but occurs more or less permanently on the coastal vegetation or in the patches in the water very close to the coast. Capture-mark-reencounter results show that the same male may occur in locations at least $80 \mathrm{~m}$ apart. Therefore, one may speak not only of small home ranges ('territories'), that are owned by the male exclusively short-term (several days), but also of his broader home range that overlaps with home ranges of many other males. It has been convincingly shown that a male displaced from his home range may return after one or several days of absence and regain his old holding, and retain it for a considerable time.

Perch as the functional centre of the small home range. The maximum period of residence of a Banded Demoiselle male in a given perch and its closest vicinity was, according to our observations, 8 days, and with a one-day gap, 10 days. In Beautiful Demoiselles the respective figure is 4 days, and with a one-day gap, 6 days. However, in this gap day (9 June 2013) inclement weather prevailed, so it cannot be ruled out that this male was present 6 days without interruption.

Perches that are preferred by different males that replace one another during the breeding season, may be regarded their activity centres and structural cores of their small home ranges. Perches and adjacent parts of the lower vegetation layer form the core area of the plots, whose borders are very uncertain. Therefore we prefer to use the term 'small home range' (further ' $p l o t$ ') rather than 'territory', even though the latter term is widely accepted in the damselfly literature.

It seems that males actually compete for the perches rather than for plots per se. Our observations suggest that stability of using of the main perch by the male is a rather good predictor of his subsequent fate as plot owner. This conclusion was made on the basis of three episodes of changing plot owners. It appeared that when the male is an exclusive owner of a plor, he spends most of his time on the primary perch, even though he may also use 2-3 secondary ones, located 1.5-2 from the main one.

The male does not remain stationary for long; he regularly takes off and returns to the same perch or to another one in the same area. We distinguish between (1) spontaneous take-offs and (2) those provoked by arrival of another male (less often of a female) in the plot. During the 4 hours of uninterrupted observations of a marked Banded Demoiselle male, of 274 take-offs 232 were spontaneous ones and just $42(15.3 \%)$ were provoked. After 131 take-offs $(47.8 \%)$ the male returned to the same perch. Frequency of spontaneous take-offs follows the endogenous cycles in locomotory activity, carrying the secondary advertising function [Panov et al., 2010]. Some authors are convinced that these flights are always aimed at foraging [HilfertRüppell, 1999], but we have some doubts, hence the neutral term 'spontaneous take-offs'.

It is the regular pattern of spontaneous take-offs which makes aggregations of male demoiselles reminiscent of lekking behaviour of some birds, which attract sexually competent females to these arenas. During the peak breeding season of demoiselles, when density of reproductive aggregation of males is high, nearly every such act triggers a take-off of a neighbour male, then of his neighbours and further as a chain reaction. As a result, something like swarms of 4-6 males is formed. Thus, a high dynamic density of flying males is constantly maintained in the aggregation, which attracts females. Spontaneous take-offs that occur in the FF regime, are a part of prelude for copulation.

What concerns triggered take-offs, a significant part of them results in short aerial confrontation with the intruder, usually in joint DF (less often, in an attempt to approach the female without leaving the home range). It is noteworthy than when a male is closely associated with his plot he avoids unnecessary prolonged interactions with other males. It is clearly shown by the short mean duration of provoked take-offs, just ca. $10 \mathrm{~s}$. Furthermore, in more than one-half of all cases $(52.4 \%$, $n=45$ ) the male after a triggered take-off returns to the initial perch.

During this period of stable association with his plot, the male often ignores males flying by and even does not take off at their arrival. He also ignores the conflicts of neighbours. It seems that during this period, the rule is "don"t leave the perch' (DLP).

Two owners of neighbouring plots regularly interact and involve in joint DF. They are each other's sparring partners ('dear enemies', [Temeles, 1994]). Even if such interactions stop being short-term and last for several minutes, it usually does not result in any changes in status of plot owners. In our opinion, these regular 
joint actions may help reset the co-called "action specific energy", following the basic principles of ethology [Lorenz, 1937].

Change of plot owners. Observations of a marked male in the evening (17:00-20:00) during 5 days (1418 July) suggest that even in the absence of pretenders, the loss of the constant link to the initially preferred perch leads to weakened relationship to the plot. In the evening of $18 \mathrm{July}$, on the eve of its disappearance, this male started to roam broadly and to visit the currently unoccupied patches in the settlement, where he met no opposition.

As mentioned earlier, when competing for a perch, male Banded Demoiselles may ignore the individual distance and approach an opponent tightly when trying to evict him. This is not typical of Beautiful Demoiselles: in this species, agonistic interactions are less tense.

It is well known that plot owners often change because one male evicts another one [Plaistow, SivaJothy, 1996]. However, we disagree with interpretations of the authors. They write: '[e]scalated flights differed from the brief $(2-10 \mathrm{~s})$ pursuit flights during which territorial males chased intruders out of their territory. By contrast escalated flights proceeded through several stages of hierarchical escalation, during which flight speed increased, and culminated in a high speed, spiralling chase that spanned the whole reproductive site. Contests between males were considered to be over when the successful male had defended the territory for at least 10 min without any further inference from the losing male' [Plaistow, Siva-Jothy, 1996: 1234].

The only part which is correct in this citation is the statement of increasing intensity of flights when grading from DF into CF, even though brevity of the description does not give a correct idea of the sequence of events. Below we present a transcript of a video of a conflict between Banded Demoiselle males.

Example 3. 19.07.2010. On 16-18 July, the plot was occupied by male \# 51 which had participated in four copulations. On the latter date, the plot was acquired by male \# 70 , which on the next day (19 July) copulated at 14:55, 16:42 and 16:57. At 17:24, a pretender appeared, which started to insistently land in the plot. Male \# 70 in response started to rush across the plot (multiple RF). At 17:32, male \# 51 started to claim the plot for himself. As a response, the same reactions (not approaching the pretender!). At 17:43, \# 70 started to land regularly to his perch and at 17:51, evicts \# 51 . He returned to the condition in which the "don"t leave the perch' (DLP) rule is valid. This is suggested by the fact that he tolerates the presence of an unmarked male in the plot. Thus condition is however not stable. In the subsequent 10 min when the male \# 51 appears again, the male \# 70 resumes $\mathbf{R F}$, even though the pretender is still hesitant and remains 4 $5 \mathrm{~m}$ from the plot centre. Male \# 70 is besieged by two more unmarked males. One of them does not take off in response to a frontal attack by \# 70, but just takes the posture shown in Fig. 5. The DLP programme still continues to act in the male \# 70. He just temporarily joins FF of the two unmarked males, without longer interactions with them, and quickly lands. At 18:30 he starts spontaneous take-offs. By the end of observations (20:07) he still owns his customary perch.
20.07.2010. At 18:30 the male \# 70 is at the same spot. Soon he tries to contact a female. Later he starts to move broadly and feverishly across the plot (in some cases DF). At 19:05 two intruder males enter. Male \# 70 flies together with them (FF); sometimes flight tracks become longer, and flight speed increases. The flight of \# 70 starts to look like RF. At 19:12, male \# 51 starts to land actively into the plot. At 19:21, he already actively conflicts with the owner (FF), at 19:26 both of them temporarily switch to $\mathbf{C F}$ of medium intensity, after which $\mathbf{F F}$ are resumed. At 19:28, the conflict reaches a high intensity (joint CF). The male \# 51 landed first. He enters the DLP condition. He lands immediately after a short participation in joint $\mathbf{F F}$ with two intruder males, and at 19:40 stops to respond to intruders and starts to perform spontaneous take-offs. The male \# 70 was last seen at 19:55 in the middle of the river some $30 \mathrm{~m}$ from his old home range.

Two more such sessions of observations of plot owner switching in male Banded Demoiselles and one case in Beautiful Demoiselles show that this is a typical sequence of events.

It is apparent that no fighting occurs here, but rather a war of nerves [Caryl, 1981]. Most importantly, in these situations the home range owner does not land either to the main perch, or to any other perches, even when they remain vacant. The intruder persistently lands within the home range at any opportunity and tries to occupy the primary perch.

The conflict may be decided within 60-90 minutes. If the original owner ventures upon sitting on the disputed perches at least several times in a row, he has a large chance to retain his rights on the plot. This chance is inversely related to flight activity of such a male. If the intruder lands on the perch each time with the initial persistence, he wins the contest and gains the exclusive rights for this particular patch. Such conflicts may last for many hours. In this case, owner switching is the most probably outcome. The winner is the one who is the first to stop the nervous breakdown, occupy the contested perch and by the virtue of that, switch to the DLP programme.

Returning to the phenomenon of spontaneous takeoffs, it should be hypothesized that their dynamics if somehow related to the social status of the male and his current reproductive potential. We could see that a pretender male, after evicting the previous owner, immediately starts to perform spontaneous take-offs, whereas the number of triggered take-offs drops, i.e. the autonomous DLP programme is launched. On the other hand, spontaneous take-offs are much less frequent in males that have abandoned their home range or were evicted to the periphery of the aggregation.

That during CF-type interactions each participant acts autonomously, so that there is no chaser and the chased, is supported by lacking clear distinction between this type of flight and RF, performed solo. Joint intense CFs do not start from diminishing distance between the male, which should be expected if one male attacks the other one, but, conversely, from increasing flight speed and longer tracks. It is only secondary that the dragonflies approach each other and start to spiral. Exactly the same alternation of increasing distance (like 
Table 1. Mating duration and the concomitant events in C. splendens and C. virgo, s. Таблица 1. Длительность спаривания и сопутствующие события у C. splendens и $C$. virgo, сек.

\begin{tabular}{|l|c|c|c|}
\hline Stages of copulation & C. splendens & C. virgo & Significance of difference \\
\hline 1. Preparation & $\begin{array}{c}6-25 ; \text { mean } 14 \pm 2 \\
(\mathrm{n}=19) ; \text { median }=14\end{array}$ & $\begin{array}{c}6-60 ; \text { mean } 23 \pm 3 \\
(\mathrm{n}=25) ; \text { median }= \\
20\end{array}$ & $\begin{array}{c}\text { means (t-test) } p=0.01 ; \\
\text { medians (Mann-Whitney } \\
\text { test }) p=0.03\end{array}$ \\
\hline 2. Coitus & $\begin{array}{c}45-201 ; \text { mean } 108 \pm 8 \\
(\mathrm{n}=27) ; \text { median }=98\end{array}$ & $\begin{array}{c}47-165 ; \text { mean } 106 \pm 6 \\
(\mathrm{n}=32) ; \text { median }=98\end{array}$ & $\begin{array}{c}\text { means (t-test }) p=0.84 ; \\
\text { medians (Mann-Whitney } \\
\text { test }) p=0.79\end{array}$ \\
\hline $\begin{array}{l}\text { 3. Female remains at the } \\
\text { site of copulation }\end{array}$ & $\begin{array}{c}0-48 ; \text { mean } 21 \pm 3 \\
(\mathrm{n}=22) ; \text { median }=19\end{array}$ & $\begin{array}{c}0-138 ; \text { mean } 62 \pm 9 \\
(\mathrm{n}=19) ; \text { median }=60\end{array}$ & $\begin{array}{c}\text { means (t-test) } p=0.0003 ; \\
\text { medians (Mann-Whitney } \\
\text { test }) p=0.001\end{array}$ \\
\hline
\end{tabular}

Range of values (min - max); means $\pm \mathrm{SE}$, (sample size) and medians are given.

during RF) and decreasing distance between the participants is observed further, throughout the interaction.

Another important point is that these flights are not linked to the topography of home ranges: the males ascend high into the air (3-4 $\mathrm{m}$ high) and move gradually, sometimes several tens of metres from the site where the conflict started (see also in [Plaistow, Siva-Jothy, 1996]). That is why Pajunen [1966: 208] correctly believes that CF is a deviant form of aggressive behaviour, useless for territory defence (see also [Caryl, 1981: 222]).

\section{Socio-sexual behaviour}

Copulation. Significant between-species variation in the behaviour of males prior to copulation has been described earlier. Unlike the highly stereotypical manner of Beautiful Demoiselle males, male Banded Demoiselles seem to be able to better adjust to a rapidly changing situation. Below is a description of another such interaction.

Example 4. 18.13.48 - a male is sitting on his main perch; 18.13 .59 - some $1.5 \mathrm{~m}$ from him a female rushes by. The male was heading towards the direction from which the female appeared, immediately flies by $\mathbf{F F}$ to the water surface in front of him. However, having "realised" that the female disappeared in the opposite direction, he does not drop into the water, but turns in midair and follows the female by FF; 18.14.03 the female returned flying rapidly, made a sharp turn and flew towards the same direction as during the first appearance (her flight speed was so high that the image was blurred in the video). The male rushed behind her and retuned to the perch; 18.14 .06 - the female rushed by the sitting male, and he dropped into water and stayed there for 3 seconds, weakly moving his wings (clapping) and because of that slightly turning right and left. During this period, the female arrived and sat at the male's perch. The male took off from the water surface by FF (18.14.09) and sat behind the female $2-3 \mathrm{~cm}$ from her (18.14.11). His wings are trembling, then he widely opened them three times (WC score 6), and then started to open the wings for the fourth time, takes off by FF (18.14.18) and flies, but not towards the female, but horizontally backwards and them immediately towards her; tries to copulate (18.14.18). The female does not allow a copulation and takes off (18.14.23); the male pursues her by
FF, touching the water in flight. 18.14.24 - the female returns and lands on the male's perch. He pursued her closely by $\mathbf{F F}$ and tries to copulate. She does not allow that, flies away, and at 18.14.27 lands on a grass stem 2-3 $\mathrm{m}$ from the male's main perch. The male made a passing copulation attempt below and behind her, takes off by FF and at 18.14.29 performs a copulation.

The whole episode, since the appearance of the female in the home range until copulation, lasted for exactly 30 seconds. Throughout this period, the male was flying only by FF, when his wings are moving so fast that for a human eye they look blurred. During this episode the possibility for the female to see the male's wings spread occurred three times during 7 seconds (18.14.11-18.14.18), but the male was then behind the female. We therefore suggest that what is important for the female in the communicative context is the general pattern of the male's behaviour, the whole sequence, but not his particular movements or phenotypic characteristics (e.g. the breadth of the blue band across the wings). It will the further treated on in the Discussion.

The male usually sits directly on the female's head, bends his abdomen and grabs by its end the cervical part of the female. Then he by actively flapping his wings ascends and lifts up the female, so that she can touch by her genital pore the male's aedeagus (stage 1 in Tab. 1). If the mating attempt is a forced one, the female resists, so that contact of genitalia occurs very rarely (in one episode, after 19 attempts by a Banded Demoiselle male, which lasted for nearly $6 \mathrm{~min}$ ). Such cases were excluded from the sample of copulation durations in Tab. 1. It seems that Beautiful Demoiselle females are more yielding in this respect.

During coitus, the base of the male's abdomen is rhythmically raised and lowered into the initial position. The frequency of these movements varies during the process from $0.66-0.87 \mathrm{~Hz}$ to $0.54-0.59 \mathrm{~Hz}(n=3)$. This frequency agrees with the data on ebony jewelwings (C. maculatus), for which mechanics and physiology of coitus in demoiselles were first reported [Waage, 1979].

Coitus duration varies broadly in both species, without apparent between-species trend (Tab. 1). If the female is receptive, the time of termination of coitus 
only depend on the male. Duration on three copulations of the same marked Beautiful Demoiselle male on 25, 29 and 30 June suggests declining sexual potential of males with time (165, 140 and $86 \mathrm{~s}$, respectively). However, this pattern is not supported by the data on a Banded Demoiselle male. In the evening of 14 July his copulation lasted for $131 \mathrm{~s}$. On the next day, one copulation was abnormally short (20 s), another one was abortive (after 10 attempts to raise the female he had to release her), and the third one reflected the speciesspecific median duration, $98 \mathrm{~s}$. Apparently, our dataset is too limited to speculate on the causes of the observed broad variation. This topic is discussed by CórdobaAguilar et al. [2009]; the data on bended and Beautiful Demoiselles are not reported in this paper.

After mating, the females remain for some time at the site. The damselfly rubs the end of its abdomen on the substrate (the possible functions of this action are described by Lindeboom [1998]. For us it is essential that in female Beautiful Demoiselles, the time gap between the end of copulation and the onset of oviposition is significantly longer than in the other species (Tab. 1). We suggest that the behaviour of sexual partners at the stage of oviposition in Beautiful Demoiselles is less coherent than in Banded Demoiselle pairs (see below). In the latter species, both partners fly down to the water after the end of copulation nearly synchronously, apparently remaining in an interaction. Longer period of inactivity of female Beautiful Demoiselles makes this development less probable.

Tandems. After the male grabs his mate, the pair may fly to another perch. Such flying tandems are much more common in Beautiful Demoiselles than in Banded Demoiselles: 27 records across 6 hours of observatons vs. single cases. Flying tandems belong to either of the two categories. It may be a female and a male that has just copulated and tries to avoid competitors trying to bereave him of the mate. In other cases, a tandem may include a female that was raised by the male from the water during oviposition. Flying tandems are usually pursued by one or several males and try to leave the highly competitive zone at the water surface. A tandem may fly a rather long distance. As a result, many copulations of Beautiful Demoiselle couples, the forced ones including, occur in the canopy, up to 4-5 m high. It agrees well with the fact that canopies are a standard part of this species habitat, in particular during nocturnal roosting. Nothing of this kind has been observed in Banded Demoiselles.

Behaviour of partners after mating. Apart from common features in the organisation of sexual contacts in both demoiselle species, some difference is also apparent.

In Banded Demoiselles the behaviour of both sexes looks well coordinated. Not just the male tries to keep as close as possible to the laying female, but the female also, when she shifts between sites suitable for oviposition, each time sits close to the male. The behaviour of the male contains all the elements which precede grabbing the female during copulation. These are FF, drop- ping into water and standing flight, or trembling. This behaviour was recorded nearly in all protocols when the male remained in the field of vision throughout the process, with a maximum duration of $37 \mathrm{~min}$ (a total of 29 video recordings). These behaviours are most apparent just when the female changes locations.

Such coordinated behaviour of mates after copulation is not typical of Beautiful Demoiselles. In many cases the male just flies away and leaves the female alone. A female ovipositing without a male is a common sight in this species (see also: [Pajunen, 1966]). During just 6 hours of observations we recorded 8 such solitary females that tried to oviposit. In four cases the female was grabbed and carried away by a male, apparently not the one with which she had mated. In two further cases, the female was carried away by alien males when ovipositing in the presence of the mate. These hijackings were usually accompanied by acute conflicts that involved two of three males. However, it would not be fair to say that male Beautiful Demoiselles never show behaviour reminiscent of Banded Demoiselles. However, it occurs in the relatively rare situations when the local density of males is low, so that plot owner manages to monopolise the area around the female.

But even in these relatively rare cases the behaviour of male Beautiful Demoiselles differs from the patterns observed in their congeners. Even though the male tries to remain near the female, his behaviour is devoid of elements so typical of male Banded Demoiselles. Sometimes one can observe a short FF, but trembling never occurs.

We believe that in Beautiful Demoiselle males the level of non-specific arousal in these social contexts is lower than in the other species. Our opinion is based on the frequency of the WC pattern and the duration of pauses within series in eight Banded Demoiselle male and five Beautiful Demoiselle males during 46 and 80 min of video records, respectively. Males of the former species performed WC with a average frequency 15 times per min, and of the latter one, 9 times per min. The median values were 0.18 and 0.08 , respectively. The means are not significantly different (t-test), mainly because the distributions are strongly non-normal. The medians are significantly different (Mann-Whitney test, $\pi=0.05)$. The mean duration of pauses between actions in WC series is $5.9 \mathrm{~s}$ in Banded Demoiselles and $12.0 \mathrm{~s}$ in Beautiful Demoiselles, the medians are 5.5 and $12.9 \mathrm{~s}$, respectively. Both means and medians are significantly different ( $\mathrm{t}$-test, $\pi=0.05$ and Mann-Whitney test, $\pi=$ $0.05)$, respectively.

The behaviour of Banded Demoiselle males in these situations may be illustrated by a 3.8 min record made after the beginning of oviposition by the female. In parentheses, duration of pauses between WC events is given in seconds.

Example 5. series 9 WC (2 $\left.\begin{array}{lllllll}2 & 3 & 5 & 3 & 2 & 3 & 5\end{array}\right)$ - flight — 2

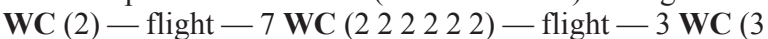
3) - 2 flights - 3 WC (1 2$)$ - flight -8 WC (2 322344 3) - flight - 6 WC ( $\left.\begin{array}{lllll}2 & 3 & 2 & 2 & 3\end{array}\right)-2$ flights (the second one towards the female) - 10 WC (2 2333 trembling 32234 
fluttering) - flight following the female - 7 WC (2 1 trembling 1233 trembling) - flight following the female - 14 WC (1 312 trembling 1212232332 fluttering)

This female was ovipositing during 33 more minutes, after which submerged. During this period, the male performed WC 265 more times. The mean duration of pauses varied considerably during the process without apparent reason, as did the number of short flights by the male. In the latter half of the session, WC series became shorter, the pauses got on average longer, the degree of spreading the wings decreased (scores 13 ), and the male started to make short flights much more frequently.

Importantly, the male's behaviour remains the same irrespectively of its position in respect to the female. Most often he performs the series of WC perched on the same spot to which he returns after short flights. The female may be located both before him, often at a considerable distance, or behind him. Her head may be directed away from the male. She is concentrated on her mission, and one can easily assume that she remains indifferent to the actions of her mate. The male continues to perform WC series (by now rather short ones) after the female becomes submerged, when he cannot see her. It look like each partner acts independently of the other one.

Ethological portraits of the species compared. One of our aims mentioned in the preamble was to present the array of species-specific behaviour of each species as a systemic syndrome. In both species, particular features of its behaviour are coherent and form well defined general patterns. Beautiful Demoiselles show greater mobility of individuals than Banded Demoiselles; the behaviour of males during social interactions is less expressive than in the latter species, and actions of mates after the copulation are less coordinated. All these features suggest a greater degree of promiscuity in the former species.

\section{Discussion}

We first mention interpretations that currently dominate the literature on demoiselle damselflies behaviour and are summarised by Córdoba-Aguilar and CorderoRivera [2005]. This paper is mentioned in nearly all publications on this topic. After that, we present our view, which is a considerably different one.

Traditional classifications of damselfly behaviours and principles of interpretation of observations. Let us take as an example the interpretations of mating behaviour of these insects. The authors emphasize its differentiation; it is called 'complex' and 'elaborate' [SivaJothy, 1999; Cannings, 2003; Córdoba-Aguilar, Cordero-Rivera, 2005]. Three patterns, which are believed to be discrete displays, namely courtship flight, dive display and cross display.

When describing each of these patterns, the authors emphasize that it is perform in the manner which allows the female to see the male's actions in the best way possible. For instance, when landing on the water the male swims with the end of his abdomen raised and 'wings spread in front of the female' [Córdoba-Aguilar, Cordero-Rivera, 2005: 867]. 'In the cross display, he faces the female and curls the tip of his abdomen dorsally, exposing the whitish ventral surface of the terminal segments' [Cannings, 2003: 2]. And further: 'when the female approaches, the male spreads his wings in front of her' or 'the male performs courtship flight-hovering in front of the female' [Waage, 1973: 240; Siva-Jothy, 1999: 1366; see also Córdoba-Aguilar, 2002: 759]. Apparently, these descriptions are only remotely similar to the pattern we have described before.

Each display is assumed to have a certain function. For instance, dive display 'demonstrates to the female both the location and the quality of the oviposition site' [Cannings, 2003]. Similar function is assumed for the cross display, namely: 'Some experiments showed that at a particular river flow rate, the probability of fungi infection in the eggs was less likely' [Siva-Jothy et al., 1995]. 'The cross display may indicate in this case how fast the flow was so that the female may get another piece of information revealing site quality' [CórdobaAguilar, Cordero-Rivera, 2005: 868].

The pattern which these authors call "cross display" is, according to our classification, a short episode of WC, when the male's wings are for a moment completely spread out. It is much more often observed after mating than during the prelude (cf. Examples 1 and 5). This is how it is explained by the authors: 'One of these is that it may serve as a form of courtship. Evidence in other insects indeed suggests that post-copulatory courtship occur in which males are still persuading the female to use the courting male's sperm' [Eberhard, 1996]. This has not been investigated in calopterygids in which a clear prediction would be that males performing the postcopulatory behaviour will get a higher fertilization success. Waage [1978] found that C. maculata females oviposited for longer when guarded by the male than when the male was not present. It would be interesting to see how male fertilization varies depending on the male's cross display [Córdoba-Aguilar, Cordero-Rivera, 2005: 874].

Johnson [2004] suggested that cross displays is used to attract the female to the oviposition site. The author assumes that this behaviour should be more frequently used by non-territorial males, which therefore "cheat" the females, pretending to be territory owners.

Many authors postulate that damselfly females are able to detect the degrees of pigmentation of wings of potential mates before copulation [e.g. Grether, 1997; Siva-Jothy, 1999]. The latter author claims that females may identify males on the basis of their wing pigmentation patterns shown in Fig. 8: 'We believe that pigmentation of male wings signals the females how well the owner can resist parasites. In C. splendens xanthostoma and $C$. haemorrhoidalis, the amount of pigmentation correlates inversely with gregarine number'. What concerns displays of wings by males, researchers have 

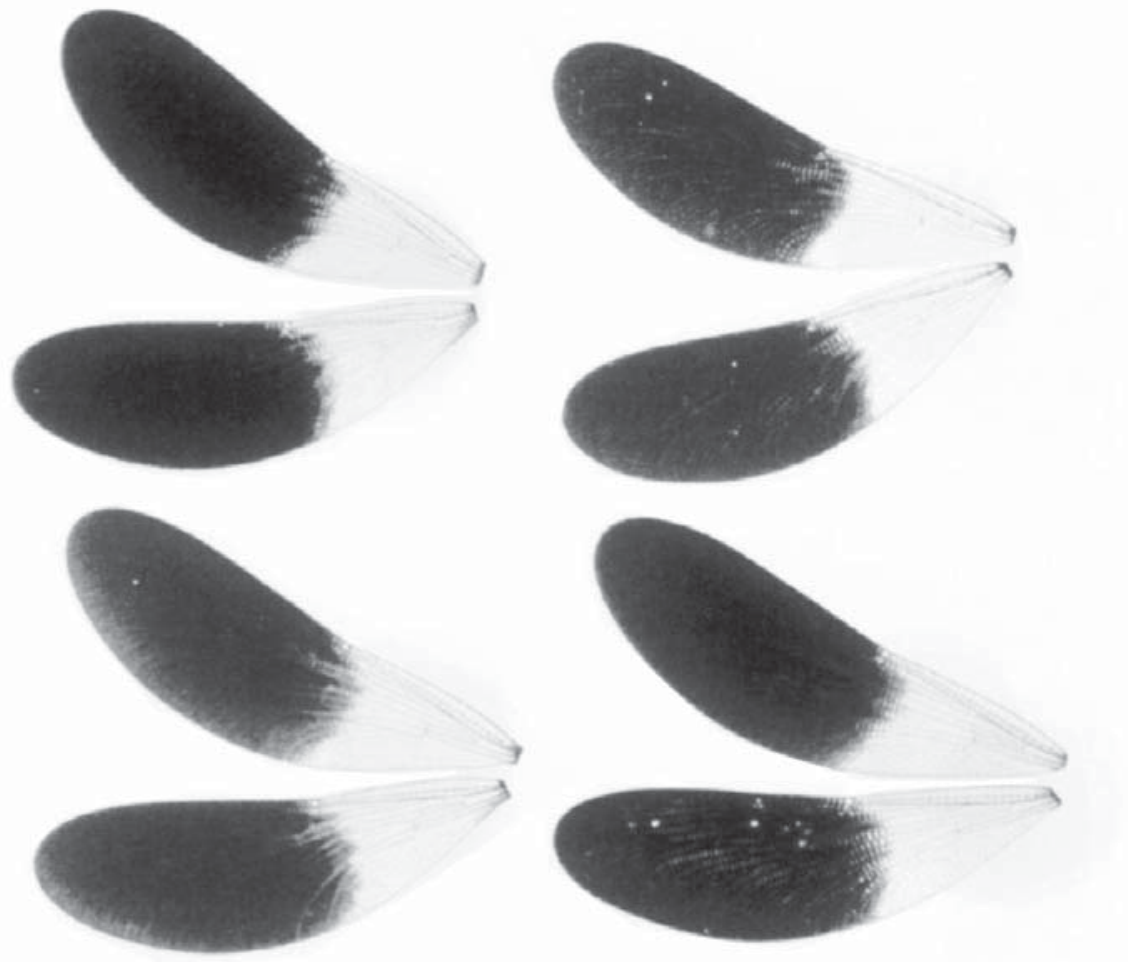

Fig. 8. Variation in extent of wings pigmentation in C. (splendens) xanthostoma males. After SivaJothy, 1999.

Рис. 8. Изменчивость в степени пигментации крыльев у самцов C. (splendens) xanthostoma. Из: [Siva-Jothy, 1999].

concluded that males may use their pigmentation patterns to communicate their resistance to gregarine infection. "An explanation for this is that the dark Calopteryx pigment evolved to communicate the male ability to deal with parasites' [Córdoba-Aguilar, Cordero-Rivera, 2005: 868].

The naive anthropomorphic approach of these interpretations makes them, in our opinion, less than useful as scientific explanations.

In the recent years it has been suggested that the very flight kinematics of males is adapted to demonstrate the colouration of their wings in the best way possible. The authors emphasize that the communicative function of flights has been missed in the study of flight aerodynamics. "Iinvestigations focused on the structural characters of the colored wings and on their behavioural and evolutionary consequences but not on the flight of the males in which the ornaments are displayed. ... Each special flight pattern appears as a conspicuous optical stimulus to which the contestant reacts by its own flight pattern [Hilfert-Rüppell, Rüppell, 2013: 120; italics ours].

On the ability of damselflies to discriminate socially important visual stimuli. The Odonata as a whole (damselflies and dragonflies) have well developed vision. Some have up to five photoreceptor types ranging from UV to long wavelengths [Briscoe, Chittka, 2001; Meinertzhagen et al., 1983; Yang et al., 1991]. Several studies founded that color signal could function in sex/ species/morph recognition [Huang et al., 2014; Grether et al., 2015]. Nevertheless, the role of visual stimulus in mate/sex recognition is somewhat conflicting. For instance, field experiments have shown that zygopterid damselflies, even when choosing a mate, may ignore not just the details of its appearance, but also the important characteristics. Gorb [1998] demonstrated to male Azure Damselflies Coenagrion puella (Coenagrionidae) models made of dead individuals and their more or less modified fragments. Males were more eager to copulate with a female model without head or thorax, than with an intact dead female. Similar results have been reported for Sympetrum anisopterid dragonflies by Mokrushov [1987] and Mokrushov and Frantsevich [1989]. Males of some Hetaerina species do not distinguish conspecific males from heterospecific males which leads to interspecific fights [Anderson, Grether, 2010, 2011].

These and similar experiments showed that '[i]n territorial damselfly and dragonfly species the most efficient stimuli that elicit a response which is adequate to the given social context, are reduced to the most basic configurations' [Frantsevich, Mokrushov, 1984; italics ours]. If the insects ignore even very important deviations from the normal appearance of mates when dealing with their static models, one can hardly assume that they are able to identify the subtle details during the brief real-time interactions (see e.g. Example 4). 


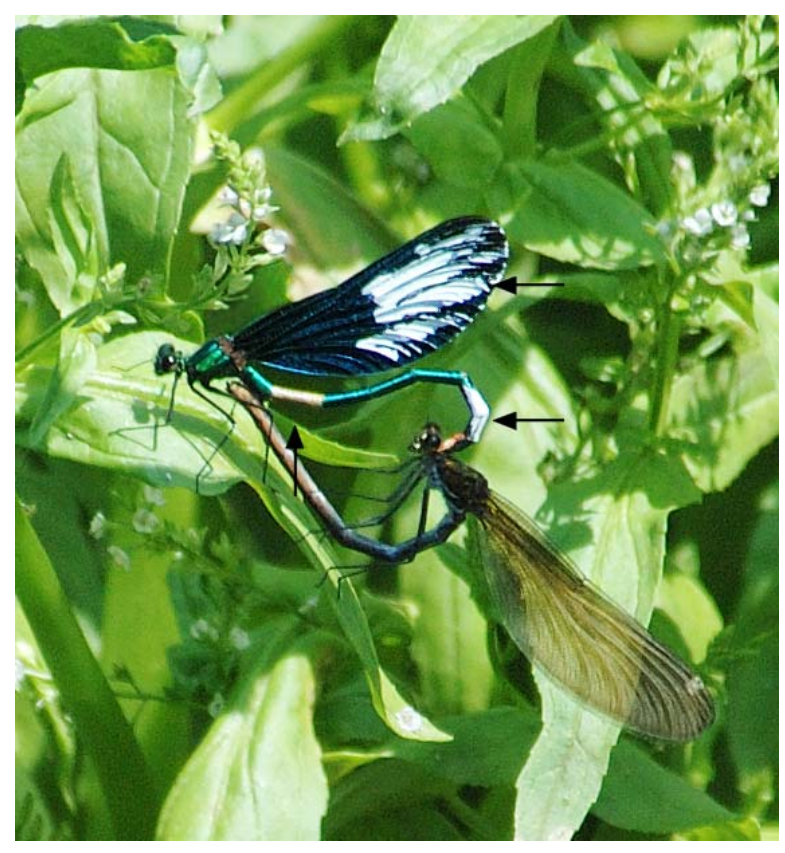

Fig. 9. Copulation by a $C$. virgo male whose appearance was changed dramatically by experimenters (marks are shown by arrows). Photo: E.N. Panov.

Рис. 9. Копуляция самца C. virgo, внешний вид которого был существенно изменен (три метки показаны стрелками). Фото Е.Н. Панова.

Experiments similar to those reported by Gorb [1998] have not, to the best of our knowledge, been performed on calopterygid damselflies. However, our data suggest that the same is valid for our model species. In both species, females have many times mated with males whose appearance had been significantly modified by bright (white and red) individual marks. Moreover, one female stopped for mating in the home range of the male whose blue fields on the wings were half covered by white paint (Fig. 9).

It would be interesting to know the response of other males to these 'white-winged' individuals. It appeared that an approach of such male to the perch of another one elicits exactly the same response as an intrusion of an intact individual. Both males participate in joint FF, which may be long enough for discrimination error to become apparent to the opponent. However, it does not happen. Similar joint flights can be performed by two white-winged males, who can be joined by naturally coloured individuals (videos available at panovethology.ru). It strongly suggests that the significant stimulus is this case is the general pattern of locomotion by the male, and not the details of pigmentation of his wings, as proposed by Hilfert-Rüppell and Rüppell [2013]. Our interpretation is further supported by joint FF of $C$. splendens and $C$. virgo males, whose wing colouration is considerably different.

Our data suggest that a receptive female does not select the male on the basis of his appearance, but a plot most suitable for oviposition (with a large number of plant stems floating on the water surface).
Our interpretations. Our first thesis is that a detailed description of demoiselle damselfly behaviour provides no evidence whatsoever that it is a set of several discrete displays with some highly specialised functions. We tried to demonstrate that many behaviours that are usually treated as such, are in reality invariant for a broad spectrum of social contexts.

Our data rather suggest that locomotor behaviour of damselflies can be much better treated as a continuum which functions on the basis of its own internal logic, e.g. endogenous rhythmicity. It is reflected in fluctuations of non-specific arousal and therefore in the level of locomotor activity. The sequence 'fluttering flight dropping into water' is a maximum in the dynamics of these conditions.

A very telling example are the $\mathrm{WC}$ movements. This is an invariant pattern which is present in the behaviour of both sexes [Bick, Bick, 1978]. This phenomenon is comparable with spontaneous vocalisation of birds, when an individual periodically or continuously gives the socalled 'calls' which are addresses to everyone and to noone in particular. This systematic repeatability of WC forced some researchers to explain it by damselfly physiology. It was assumed that it is a thermoregulatory mechanism, which is used for cooling the body at high ambient temperature [Erickson, Reid, 1989]. This assumption is however not confirmed, because our data show a considerable short-term variation in the frequency of occurrence of WC. We found an obvious decrease in its frequency in male Banded Demoiselles after copulation - from the onset of oviposition by the female to the end of the process. There is no doubt that this dynamics is a result of a gradually decreasing response of the male to the stimulus 'presence of female'.

Thus, WC which is traditionally assigned an important communicative function (demonstration by the male of the colouration of his wings to the female), in reality does not have it. This is further supported by the incontestable fact that position of the male which performs $\mathrm{WC}$, is random in respect to the female. It is not possible to show that the male performs these actions 'in front of the female'.

Another example are RF and CF, which we explain as a result of sharp increase of non-specific arousal, causing something like a nervous breakdown. Inadequacy of these behaviours for meaningful communication has been long ago emphasized by Pajunen [1966: 208].

For the sake of brevity, we restrict ourselves to these illustrations of our views. Our main point is that information is contained not in a particular pattern, but in the whole line of behaviour of an actor during interactions with a social partner, as evident, for instance, from the sequence of actions of a male in Examples 2, 4 and 5. One reason for that is the high inertia of male behaviour. After entering a certain state, he will perform the corresponding actions until something reminiscent of phase shift in physical and chemical systems happens.

In conclusion, several words are necessary on how serious ethological entomologists treat the concept of 'symptom'. Ohtani, who follows Wenner and Wells 
[1990] in denying the communicative efficiency of waggle dances of honeybees, explains the sophisticated locomotions of these insects this way: "The excessive excitement in flying may accumulate in the nervous system of the forager. ... That is, the forager might be 'pseudo-flying' on the comb surface. The same muscles and nervous system used for waggle dances are also used usually in flying and walking. If the dance performance of honeybees is caused by the leaking-out of accumulated excitement from flying, it would be not eliminated by natural selection because it is neutral in evolution' [Ohtani, 2008: 87].

Researchers who tend in see a special function evolved though natural or sexual selection in everything which somehow deviates from the patterns familiar to them, a priori see waggle dance of worker honeybees or dropping into water by a male damselfly as evidence of highly expedient behaviour of animals and insects in particular. The critique of this concept is provided by Panov [2014].

\section{References}

Anderson C.N., Grether G.F. 2010. Interspecific aggression and character displacement of competitor recognition in Hetaerina damselflies // Proc. R. Soc. Lond. Vol.277. P.549-555.

Anderson C.N., Grether G.F. 2011. Multiple routes to reduced interspecific territorial fighting in Hetaerina damselflies // Behav. Ecol. Vol.22. P.527-534.

Bick G.H., Bick I.C. 1978. The significance of wing clapping in Zygoptera // Odonatologica Vol.7. P.5-9.

Briscoe A.D., Chittka L. 2001. The evolution of color vision in insects // Ann. Rev. Entomol. Vol.46. P.471-510.

Cannings S.G. 2003. Status of River Jewelwing (Calopteryx aequabilis Say) in British Columbia // Wildlife Bull. No.B-110. P.1-10.

Cary P.G. 1981. Escalated fighting and the war of nerves: Game theory and animal combat // Perspectives in Ethology. Springer US. P.199-224.

Corbet S.A. 1991. A fresh look at the arousal syndrome of insects // Adv. Insect Physiol. Vol.23. P.81-116.

Córdoba-Aguilar A. 2002. Wing pigmentation in territorial male damselflies, Calopteryx haemorrhoidalis: a possible relation to sexual selection // Anim. Behav. Vol.63. No.4. P.759-766.

Córdoba-Aguilar A., Cordero-Rivera A. 2005. Evolution and ecology of Calopterygidae (Zygoptera: Odonata): status of knowledge and research perspectives // Neotropical Entomol. Vol.34. No.6. P.861-879.

Córdoba-Aguilar A., Serrano-Meneses M.A., Cordero-Rivera A 2009. Copulation duration in nonterritorial odonate species lasts longer than in territorial species // Ann. Entomol. Soc. America. Vol.102. No.4. P.694-701.

Erickson C.J., Reid M.E. 1989. Wingclapping behavior in Calopteryx maculata (P. de Beauvois) (Zygoptera: Calopterygidae) // Odonatologica. Vol.18. P.379-383.

Frantsevich L.I., Mokrushov P.A. 1984. Visual stimuli releasing attack of a territorial male in Sympetrum (Anisoptera, Libellulidae) // Odonatologica. Vol.13. P.335-350.

Grether G.F. 1997. Survival cost of an intrasexually selected ornament in a damselfly // Proc. R. Soc. Ser.B. Vol.264. No.1379. P.207-210.

Grether G.F., Drury J.P., Berlin E., Anderson C.N. 2015. The role of wing coloration in sex recognition and competitor recognition in rubyspot damselflies (Hetaerina spp.) // Ethology. Vol.121. P.674-685.

Günther A. 2015. Signalling with clear wings during territorial behavior and courtship of Chlorocypha cancellata (Odonata, Chlorocyphidae) // Int. J. Odonatology. Vol.18. No.1. P.45-54.
Günther A., Hilfert-Rüppell D., Rüppell G. 2014. Reproductive behaviour and the system of signalling in Neurobasis chinensis (Odonata, Calopterygidae) - a kinematic analysis // Int. J. Odonatology. Vol.17. No.1. P.31-52.

Hayashi Y., Yuki M., Sugawaraa K., Kikuchi T., Tsuji K. 2012. Rhythmic behavior of social insects from single to multibody // Robotic. Autonom. Syst. Vol.60. P.714-721.

Hilfert-Rüppell D. 1999. To stay or not to stay: decision-making during territorial behaviour of Calopteryx haemorrhoidalis and Calopteryx splendens splendens (Zygoptera: Calopterygidae) // Int. J. Odonatology. Vol.2. No.2. P.167-175.

Hilfert-Rüppell D., Rüppell G. 2009. Males do not catch up with females in pursuing flight in Calopteryx splendens (Odonata: Calopterygidae) // Int. J. Odonatology. Vol.12. No.2. P.195203.

Hilfert-Rüppell D., Rüppell G. 2013. Do coloured-winged damselflies and dragonflies have flight kinematics different from those with clear wings? // Int. J. Odonatology. Vol.16. No.2. P.119-134.

Howse P.E. 1975. Brain structure and behavior in insects // Ann. Rev. Entomol. Vol.20. No.1. P.359-379.

Huang S., Chiou T., Marshall J., Reinhard J. 2014. Spectral sensitivities and color signal in a polymorphic damselfly // PLOSOne. Vol.9. P.1-8.

Johnson J. 2004. Flashing your bling: male Calopteryx maculata displays, territoriality and body morphology. http:// en.scientificcommons.org/22614808.

Kuitunen K., Gorb S.N. 2011. Effects of cuticle structure and crystalline wax coverage on the coloration in young and old males of Calopteryx splendens and Calopteryx virgo // Zoology. Vol.114. No.3. P.129-139.

Lindeboom M. 1998. Post-copulatory behaviour in Calopteryx females (Insecta, Odonata, Calopterygidae) // Int. J. Odonatology. Vol.1. No.2. P.175-184.

Lorenz Ê. 1937. Ueber den Begriff der Instinkthandlung // Folia biotheor. (Leiden). Bd.2. S.17-50.

Meinertzhagen I.A., Menzel R., Kahle G. 1983. The identification of spectral receptor types in the retina and lamina of the dragonfly Sympetrum rubicundulum // J. Comp. Physiol. Vol.151. P.295310 .

Misof B., Anderson C.L., Hadrys H. 2000. A phylogeny of the damselfly genus Calopteryx (Odonata) using mitochondrial 16S rDNA markers // Mol. Phyl. Evol. Vol.15. P.5-14.

Mokrushov P.A. 1987. [The role of visual stimuli in mate recognition in Sympetrum dragonflies] // Vestnik zoologii. Vol.4. P.52-57 [in Russian, with English summary].

Mokrushov P.A., Frantsevich L.I. 1989. [Ethological studies of Sympetrum dragonflies] // Mordkovich V.G. (ed.). Fauna i ekologiya strekoz. Novosibirsk: Nauka. P.108-118 [in Russian, with English summary].

Ohtani T. 2008. Recruitment efficiency of waggle dances performed by a worker honeybee and the influence on her dance performance by recruited foragers // Humans and Nature. Vol.19. P.71-88.

Opaev A.S., Panov E.N. (in press). Movements of male Banded Demoiselles (Calopteryx splendens: Zygoptera, Odonata) in the reproductive period: do they have distinct spatial strategies? // Zool. Zhurn.

Panov E.N. 2014. [Sexual Selection: Theory or Myth. Field Zoology against Armchair Knowledge]. Moscow: KMK Scientific Press Ltd. 453 p. [in Russian, with English summary]

Panov E.N., Opaev A.S., Pavlova E.Yu. 2010. [Social organization in reproductive aggregations and mating behavior in damselflies Calopterigidae (Insecta: Odonata)] // Ethol. Zoopsychol. Vol.2. P.1-31 [in Russian, with English summary].

Pajunen V.I. 1966. Aggressive behaviour and territoriality in a population of Calopteryx virgo L. (Odon., Calopterygidae) // Ann. zool. fennici. Vol.3. P.201-214.

Plaistow S., Siva-Jothy M.T. 1996. Energetic constraints and male mate-securing tactics in the damselfly Calopteryx splendens xanthostoma (Charpentier) // Proc. R. Soc. Ser.B. Vol.263. No.1374. P.1233-1239.

Rüppell G. 1989. Kinematic analysis of symmetrical flight manoeuvres of Odonata // J. Experiment. Biol. Vol.144. No.1. P.13-42. 
Siva-Jothy M.T. 1999. Male wing pigmentation vay affect reproductive success via female choice in a Calopterygid damselfly (Zygoptera) // Behaviour. Vol.136. No.10/11. P.1365-1377.

Stettmer C. 1996. Colonisation and dispersal patterns of banded (Calopteryx splendens) and Beautiful Demoiselles (C. virgo) (Odonata: Calopterygidae) in south-east German streams // European J. Entomol. Vol.93. No.4. P.579-593.

Temeles E.J. 1994. The role of neighbors in territorial systems: when are they «dear enemies»? // Anim. Behav. Vol.47. No.2. P.339350

Tynkkynen K., Grapputo A., Kotiaho M.J., Rantala S., Väänänen S., Suhonen J. 2008. Hybridization in Calopteryx damselflies: the role of males // Anim. Behav. Vol.75. P.1431-1439.

Waage J.K. 1973. Reproductive behaviour and its relation to territoriality in Calopteryx maculata (Beauvois) (Odonata: Calopterygidae) // Behaviour. Vol.47. P.240-256.

Waage J.K. 1979. Dual function of the damselfly penis: sperm removal and transfer // Science. Vol.203. No.4383. P.916-918.
Waage J.K. 1984. Female and male interactions during courtship in Calopteryx maculata and C. dimidiata (Odonata: Calopterygidae): influence of oviposition behavior// Anim. Behav. Vol.32. No.2. P.400-404.

Wellenreuther M., Larson K.W., Svensson E.I. 2012. Climatic niche divergence or conservatism? Environmental niches and range limits in ecologically similar damselflies // Ecology. Vol.93. No.6. P.1353-1366.

Wenner A.M. 2002. The elusive honey bee dance "language" hypothesis // J. Insect Behav. Vol.15. P.859-878.

Wenner A.M., Wells P.H. 1990. Anatomy of a controversy - the question of a "language" among bees. New York: Columbia Univ. Press. 399 p.

Yang E.C., Osorio D. 1991. Spectral sensitivities of photoreceptors and lamina monopolar cells in the dragonfly, Hemicordulia tau // J. Comp. Physiol. Vol.169. P.663-669. 